\title{
Leszek Żyliński*
}

\section{Pośrednik między światami. Karl Dedecius (1921-2016)}

DOI: http://dx.doi.org/10.12775/LC.2016.012

ażda literatura jest prowincjonalna, dopóki nie wyjdzie poza własny język. Na pewno dotyczy to narodów małych i średnich, których kultury potrzebują pośredników, aby zaistnieć w powszechnej świadomości. Dla literatury polskiej takim niestrudzonym pośrednikiem był Karl Dedecius, który zmarł 26 lutego 2016 roku we Frankfurcie nad Menem w wieku 94 lat.

Dedecius urodził się 20 maja 1921 roku w Łodzi. Rodzina miała niemieckie i czeskie korzenie, jego przodkowie ze strony matki przybyli ze Szwabii, zaś ze strony ojca ze Śląska. W czasie, gdy przyszedł na świat, jego niemiecka rodzina była już mocno spolonizowana. Rodzice - jak pisze Dedecius w swych wspomnieniach - kończyli w Kongresówce rosyjskie szkoły, matka mówiła po niemiecku i czytała tylko Biblię, z ojcem natomiast rozmawiał po polsku i takiego języka ojciec używał też na co dzień w pracy. Po latach Dedecius zdziwi się nawet swemu wyborowi języka niemieckiego jako przedmiotu maturalnego w łódzkim gimnazjum, gdyż: „Po niemiecku rozmawiałem właściwie tylko z matką i była to niemczyzna skromna, ograniczona wyłącznie do słownictwa nieodzownego w sprawach domowych. Codziennym językiem, którego używałem na ulicy, w urzędach, w szkole, w czasie wolnym, w kontaktach ze szkolnymi kolegami i przyjaciółmi, niezależnie od tego, czy byli Niemcami, Żydami czy Polakami, był polski, i to nie z mojego świadomego wyboru, tylko dlatego, że poza domem było to naturalne i praktyczne. Dzisiaj nadal jestem skłonny wierzyć, że moja polszczyzna prezentowała się wówczas lepiej niż mój niemiecki, była przede wszystkim bo-

* Leszek Żyliński - profesor zwyczajny w Katedrze Filologii Germańskiej UMK, kierownik Zakładu Literatury i Kultury XIX i XX wieku, członek Niemieckiej Akademii Języka i Literatury. Ostatnio opublikował Od Prus do Europy. Szkice o tożsamości narodowej Niemców (Toruń 2014) 
gatsza - całe słownictwo nauk przyrodniczych, fizyki, matematyki, historii, językoznawstwa i filozofii przyswoiłem sobie bowiem po polsku, a nie po niemiecku. Biblioteki w naszym małym domu nie było. Dziś już nie pamiętam, ale mówili mi szkolni koledzy, że wypożyczałem codziennie nową książkę z biblioteki szkolnej. Uchodziłem za maniaka czytania. Pamiętam, z jaką trudnością przychodziło mi po powrocie z niewoli sowieckiej, kiedy w wieku prawie trzydziestu lat znalazłem się po raz pierwszy w Niemczech, nazywać różne rzeczy i sprawy po niemiecku."

Przyszły tłumacz wychował się w Łodzi, tam w 1939 roku ukończył polskie gimnazjum, co na trwale zakorzeniło go w polskiej kulturze. W swych autobiograficznych esejach wielokrotnie przywoływał wielojęzyczny i wielokulturowy tygiel łódzki oraz gimnazjum im. Stefana Żeromskiego, które uformowały go jako człowieka otwartego na polifonię głosów i poglądów. „Łódzkiej szkole przede wszystkim zawdzięczam wychowanie do współżycia i współpracy z ludźmi różnych narodowości, różnego wyznania, różnego pochodzenia, różnych poglądów. Łodzi zawdzięczam również naturalny stosunek do pracy, do codziennych obowiązków i codziennej odpowiedzialności”2.

Życie dobrze zapowiadającego się młodzieńca przerwane zostało wybuchem drugiej wojny światowej, wcieleniem do Wehrmachtu, siedmioletnią niewolą w ZSRR i utratą najlepszych lat, które zamiast w uniwersyteckiej czytelni i na wykładach spędził Dedecius w okopach i łagrze. Nie stracił jednak pogody ducha i optymizmu, które pozwoliły po powrocie „do obcego kraju”, jak wówczas odbierał Niemcy, rozpocząć nowe życie. Po krótkim intermezzo w Weimarze w NRD pod koniec 1952 roku wraz z rodziną przeniósł się na zachód. Ale tam również trudno dałoby się żyć z przekładów poezji, co stało się pasją dla nie mającego żadnego konkretnego zawodu trzydziestolatka (nawet w niewoli przekładał rosyjskich poetów na niemiecki). I tak Karl Dedecius spędził kilkadziesiąt kolejnych lat w podwójnej roli; zawodowo jako urzędnik towarzystwa ubezpieczeniowego we Frankfurcie nad Menem zarabiał na życie, aby w wolnym czasie tłumaczyć swych ulubionych poetów.

Poetyckie predyspozycje nosił w sobie od szkolnych lat. Czytając Mickiewicza i Tuwima kształcił słuch, wyczucie rytmu i rymu, szlifował frazę własnego zdania. Jako młody gimnazjalista pisał też oryginalne wiersze. „Wojna zniszczyła mi je: zewnętrznie i wewnętrznie. Potem przyszły lata niewoli (refleksji), które nauczyły mnie nie brać siebie zbyt serio i z uwagą przysłuchiwać się innym. Wyrósłszy w środowisku dwujęzycznym miałem i tak zainteresowania poetyckie wykraczające poza granice jednego języka”

Translatorską pozycję Dedeciusa wyznaczyły przekłady polskich poetów. Właśnie wiersze umiłował najbardziej, im poświecił setki godzin i zyskał nowy świat i nowe przyjaźnie. Pracę wykonał tytaniczną, co sucho, ale dobitnie potwierdza spis wydanych tomów poetyckich, antologii, esejów. Polska humanistyka doceniła jego wybitną rolę, o Dedeciusie z uznaniem pisali Kazimierz Wyka i Egon Naganowski, Jan Koprowski i Stanisław Barańczak. Już pierwsze antologie, wydane w 1959 roku jako jaskółki nieznanej, niemal egzotycznej literatury niby-sąsiada, wobec którego Niemcy odczuwali winę pomieszaną z uprzedzeniem, zostały odebrane jako przełom. Lekcja ciszy (Lektion der Stille) jako antologia nowej liryki z Polski doczekała się w pierwszym roku od razu dwóch wydań. Wydań - dodajmy - przy-

\footnotetext{
1 K. Dedecius, Europejczyk z Łodzi. Wspomnienia, przeł. S. Lisiecka, Kraków 2008, s. 71.

2 Idem, Stefan Żeromski. Łódzkie lektury obowiq̨zkowe, w: O Polsce, Europie, literaturze. Dialogi przyjaźni, Wrocław 1996, s. 96.

3 Idem, Notatnik tłumacza, przeł. Jan Prokop, Kraków 1974, s. 144.
} 
jętych entuzjastycznie przez krytyków, prasę i czytelników poezji, zadziwionych innością obrazowania i intelektualną jakością wierszy polskich autorów. Bibliofilski arkusz poetycki Płonące groby (Leuchtende Gräber) przynosił natomiast na niemiecki grunt w dwadzieścia lat po wrześniu 1939 roku wiersze poległych polskich poetów. Sam zamiar mógł szokować, ale bronił się jakością literacką wierszy, „nienaganną” warstwą językową oraz wyborem, który Kazimierz Wyka ocenił jako „doskonały”.

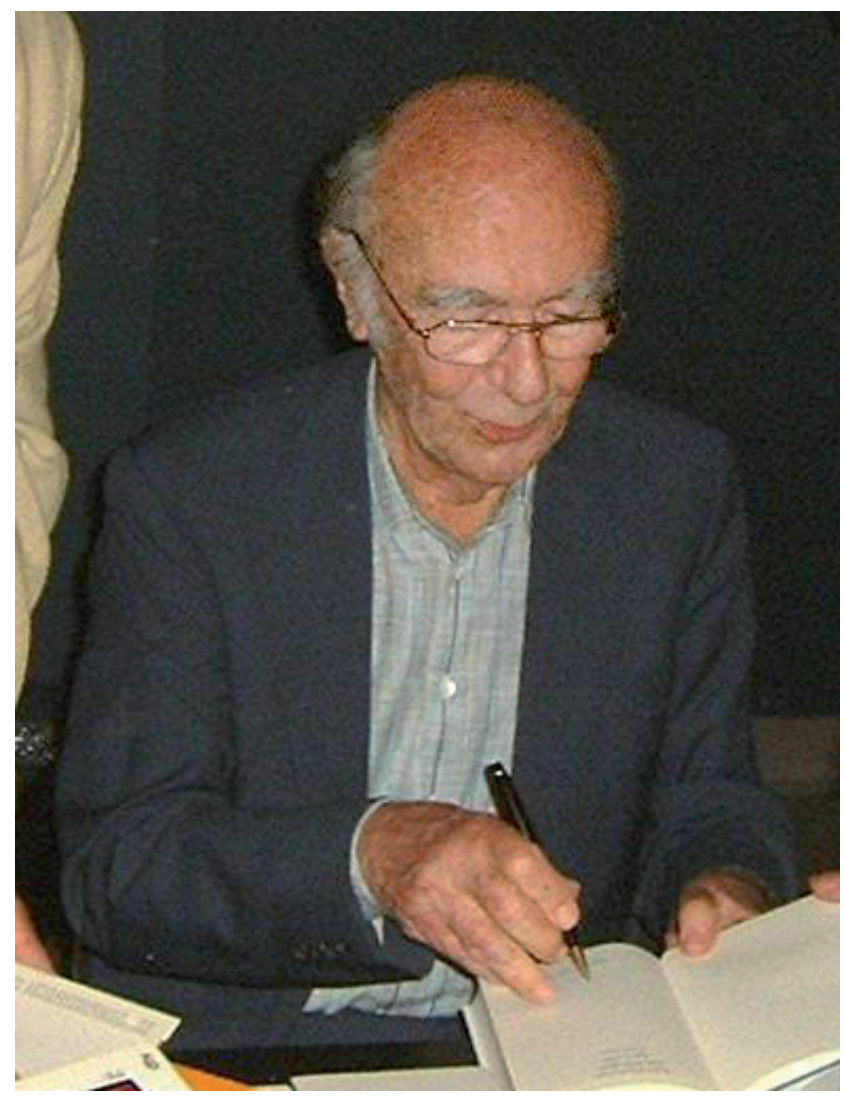

Karl Dedecius w Frankfurcie nad Menem, 14 września 2006 r.

(źródło fot. creativecommons)

Tam, gdzie historia wykopała przepaść, gdzie polityka zawodziła, gdzie pamięć dzieliła, tłumacz podejmował dzieło porozumienia i zbliżenia. Temu powołaniu Dedecius pozostał wierny w całym swym pracowitym życiu. Miłość do słowa łączyła się u niego z autentycznym i niekoniunkturalnym zadaniem budowania zrozumienia między dwoma narodami. Jak pisał jeszcze w latach siedemdziesiątych, budując samowiedzę tłumacza, „kto - zamiast budować nad babilońskim wieżowcem ogólnego nieporozumienia - zechce potrudzić się nad zniesieniem obcości miedzy ludźmi, ten ma doskonałą szansę: jako tłumacz.” A przełożył Dedecius ponad trzystu poetów i prozaików, poczynając od polskiego Renesansu po

\footnotetext{
4 K. Wyka, Płonące groby, w: tenże, Rzecz wyobraźni, Warszawa 1977, s. 546.

5 K. Dedecius, Notatnik, s.23.
} 
współczesnych. Najchętniej wybierał i tłumaczył poetów swojego pokolenia (Różewicz, Herbert, Szymborska) i poprzedzających ich mistrzów (Przyboś, Tuwim, Miłosz). Dosyć prosto uzasadniał swoje wybory: „Nie ma sensu tłumaczyć dobrych wierszy polskich poetów, jeśli podobne równie dobrze pisał jakiś niemiecki autor. Baczyńskiego u nas nie ma - tłumaczyłem, poety takiego jak Herbert u nas nie ma - tłumaczyłem, Różewicza i Szymborskiej też”. Zupełnie osobne miejsce w jego twórczości zajął jednak Stanisław Jerzy Lec, którego Myśli nieuczesane, kongenialnie przełożone i wielokrotnie wznawiane, stały się prawdziwym bestsellerem. W różnych wydaniach opublikowano w Niemczech dotychczas ponad milion egzemplarzy książki Leca. Po dziś dzień, niejako na prawach dobra publicznego, cytowane są w różnych miejscach również przez tych, którzy nie wiedzą, kto jest autorem tych aforyzmów.

W swym długim życiu Dedecius miał także szczęście budować inne trwałe dzieła. Po przejściu na emeryturę w swym pierwszym zawodzie całą energię i czas mógł poświęcić polskiej literaturze. W 1980 roku doprowadził do utworzenia placówki kulturalno-badawczej zorientowanej na propagowanie kultury polskiej. I tak pod jego kierownictwem rozpoczął działalność Deutsches Polen-Institut (Niemiecki Instytut Polski). Statut wyznaczał mu za zadanie „badanie i prezentację polskiej literatury i kultury w szerokim ujęciu, a więc w dawnej i obecnej Polsce oraz na emigracji”’ Dzięki tej niewielkiej instytucji, mającej przez kilkadziesiąt lat siedzibę w secesyjnej willi na Wzgórzu Matyldy w Darmstadt ${ }^{8}$, nawiązano setki kontaktów, zrealizowano projekty wydawnicze, naukowe, teatralne, medialne, których oddźwięk w niemieckiej przestrzeni publicznej trudno przecenić. Dla swego pomysłu potrafił Dedecius pozyskać najbardziej wpływowe osoby ówczesnej Republiki Federalnej: funkcję pierwszego prezydenta DPI pełniła do 1994 roku Marion hrabina Dönhoff, jej następcą został były kanclerz Republiki Helmut Schmidt. Najbardziej widocznym dorobkiem Instytutu - obok siedziby z najlepszą chyba polonistyczną biblioteką w Niemczech - jest kolekcja Biblioteki Polskiej. Tych pięćdziesiąt tomów wydanych w latach 1982-2000 w pięknej szacie graficznej renomowanego wydawnictwa Suhrkamp prezentuje przekrój piśmiennictwa polskiego od średniowiecza po współczesność. Książki ukazały się często w nowych tłumaczeniach, zawsze z profesjonalnym komentarzem, a całość przedsięwzięcia naukowo redagował w Instytucie Andreas Lawaty.

Taką pragmatyczną polonistykę i pedagogiczną pracę publiczną na rzecz polskiej kultury prowadził Dedecius w Instytucie do końca 1997 roku, kiedy przeszedł na emeryturę. Zbudował instytucję, której znaczenie zdecydowanie wyrastało ponad miasto Darmstadt i było niewspółmiernie wielkie w stosunku do sił dyrektora i nielicznego grona współpracowników. Działalność translatorska i publiczna Karla Dedeciusa została już wcześnie dostrzeżona zarówno w Republice Federalnej jak też w Polsce. Nagrody, wyróżnienia, członkostwa w akademiach wypełniają tak obszerną listę, że nie sposób jej zamieścić w krótkim tekście. Dedecius został m. in. doktorem honorowym siedmiu uniwersytetów, był członkiem renomowanej Niemieckiej Akademii Języka i Literatury, otrzymał najwyższe odznaczenia niemieckie i polskie (łącznie z Orderem Orła Białego), a w 2010 roku prestiżową Niemiecką Nagrodę Narodową.

\footnotetext{
6 Cyt. za K. A. Kuczyński, Czarodziej z Darmstadt. Rzecz o Karlu Dedeciusie, Łódź 1999, s. 46.

7 Cyt. za: Deutsches Polen Institut Darmstadt. Ziele und Aufgaben, Darmstadt 1980, s. 3.

8 W lutym 2016 roku Instytut rozpoczął przeprowadzkę do jeszcze bardziej reprezentacyjnych pomieszczeń w pałacu, byłej rezydencji książąt heskich w centrum Darmstadt.
} 
W osobie Karla Dedeciusa literatura polska zyskała skarb wręcz wyjątkowy. W dziesiątkach laudacji i artykułów o „ambasadorze kultury polskiej” podkreślano, ile Polacy i Niemcy zawdzięczają mu jako rzetelnemu pośrednikowi i tłumaczowi. Bez niego nie byłoby tak trwałej recepcji polskiej poezji na niemieckim obszarze językowym, a najwyższe honory, jakie odbierali Miłosz, Herbert czy Szymborska mogłyby się nie zdarzyć bez wcześniejszych niemieckich wydań ich książek. Człowiek niezwykle pracowity, artysta słowa i rzetelny „wyrobnik (poetyckiej) winnicy pańskiej” potrafil stać się również rzutkim promotorem tej literatury oraz doskonałym menedżerem własnych pomysłów.

Przy okazji tego wspomnienia warto odnotować związki Karla Dedeciusa z Toruniem. Odwiedził nasze miasto kilkukrotnie, od 1986 roku był członkiem honorowym Towarzystwa Bibliofilów im. Joachima Lelewela. Ten wybitny humanista został doktorem honorowym Uniwersytetu Mikołaja Kopernika. Podczas uroczystej promocji w 1995 roku wygłosił mowę, poświęconą postaciom toruńskiego uniwersytetu, m.in. wybitnemu filozofowi Henrykowi Elzenbergowi. Nawiązując do własnej drogi życiowej oraz patrona UMK zakończył swój wykład rekomendacją, którą ze względu na jej ponadczasowy charakter warto ponownie przywołać: „Cokolwiek, obowiązkami codziennymi obarczeni, czynimy, nad czym pracujemy, nie powinniśmy zapominać mimo wszystko o obrotach ziemi i o zjawiskach ciał niebieskich; o rzeczach na pierwszy rzut oka niechlebodajnych. Bo wtedy, być może, codzienność zyskałaby więcej szans na odkrywcze dzieła 'de revolutionibus' (1543) i w następnej kolejności (1554) 'de Republica emendanda' (już Andrzeja Frycza Modrzewskiego). Więcej szans na nowe odważne spojrzenie na świat i na poprawę Rzeczypospolitej"

Nawiązał wtedy również do innej ważnej dla niego postaci polskiej kultury. Zbigniew Herbert był tym poetą, którego wiersze Dedecius wielokrotnie tłumaczył i skutecznie propagował. Nie było więc przypadkiem, że w roku 1997 w Toruniu Dedecius został uhonorowany literacką nagrodą im. Samuela Bogumiła Lindego w parze ze Zbigniewem Herbertem, jednym z najważniejszych poetów w jego przekładowym dorobku. Ich znajomość przekształciła się w przyjaźń i żywy związek intelektualny. Dokumentuje to obszerna korespondencja, do której dzisiaj mamy wgląd w archiwum Dedeciusa, które przed kilku laty tłumacz przekazał Collegium Polonicum w Słubicach. Do Herberta nawiązał również w swym wspomnieniu związanym z nagrodą Lindego. Poproszony przeze mnie jesienią 2015 roku o kilka zdań dla przygotowywanej publikacji z okazji jubileuszu dwudziestolecia tej wyjątkowej nagrody lączącej Polaków i Niemców we wspólnej literackiej rozmowie, Dedecius napisał m. in.: "Z wielką radością i spełnieniem myślę o Toruniu, o wielu wspólnych przedsięwzięciach, ważnych przyjaźniach oraz rozlicznych honorach, jakie mnie tam spotkały. Do wyróżnień Uniwersytetu Mikołaja Kopernika (doktorat honorowy) i Towarzystwa Bibliofilów im. J. Lelewela (honorowe członkostwo) doszła nagroda im. Samuela Bogumiła Lindego, wspaniały prezent miast Torunia i Getyngi. Prezent i pomysł tym milszy memu sercu, że wyróżniono mnie wespół z mym przyjacielem Zbigniewem Herbertem. Literatura pomaga przerzucać mosty między narodami i społeczeństwami, a gdy praca poetów i tłumaczy zostaje doceniona, wzmacnia to również same społeczeństwa”"10.

9 K. Dedecius, Filozofia poezji, poezja filozofii, w: O Polsce ..., s. 58-59.

10 Tekst Karla Dedeciusa otrzymałem mailem za pośrednictwem jego sekretarki, pani llony Czechowskiej. Zostanie opublikowany wraz z wypowiedziami innych laureatów w jubileuszowej publikacji. 
Swym całym bogatym dziełem Karl Dedecius postawił sobie najtrwalszy pomnik, jaki może pozostać po twórcy. Od 2003 roku kolejni tłumacze z Polski i Niemiec, kontynuujący dzieło pośrednictwa między kulturami, wyróżniani zostają nagrodą jego imienia. Oni już $\mathrm{z}$ reguły nie noszą w sobie tego rozdarcia, jakie towarzyszyło biografii Dedeciusa i ludzi jego pokolenia. Tego, co łączyło go z prawzorem wszystkich tłumaczy, świętym Hieronimem, o którym pisał - jakby pochylając się nad własnym losem - „Był człowiekiem pogranicza. Kimś stanowiącym klamrę w czasach rozdarcia”"11.

11 K. Dedecius, Notatnik, s. 150. 